\title{
Next Generation Plant Breeding
}

Jan-Kees Goud

Laboratorium voor

Fytopathologie

Wageningen UR Plant

Breeding

Van 11-14 november 2012 vond in de Reehorst de conferentie 'Next Generation Plant Breeding' plaats. Tijdens deze bijeenkomst kwamen de grote uitdagingen van de toekomstige plantenveredeling aan de orde: de opkomst van nieuwe sequencing-technieken, de bijbehorende enorme hoeveelheid gegevens die geproduceerd wordt, inzicht in de genetica van de plant, de bijbehorende statistische methoden, en geautomatiseerde waarneming van planten. En veel meer wat hier onvermeld blijft. Een impressie.

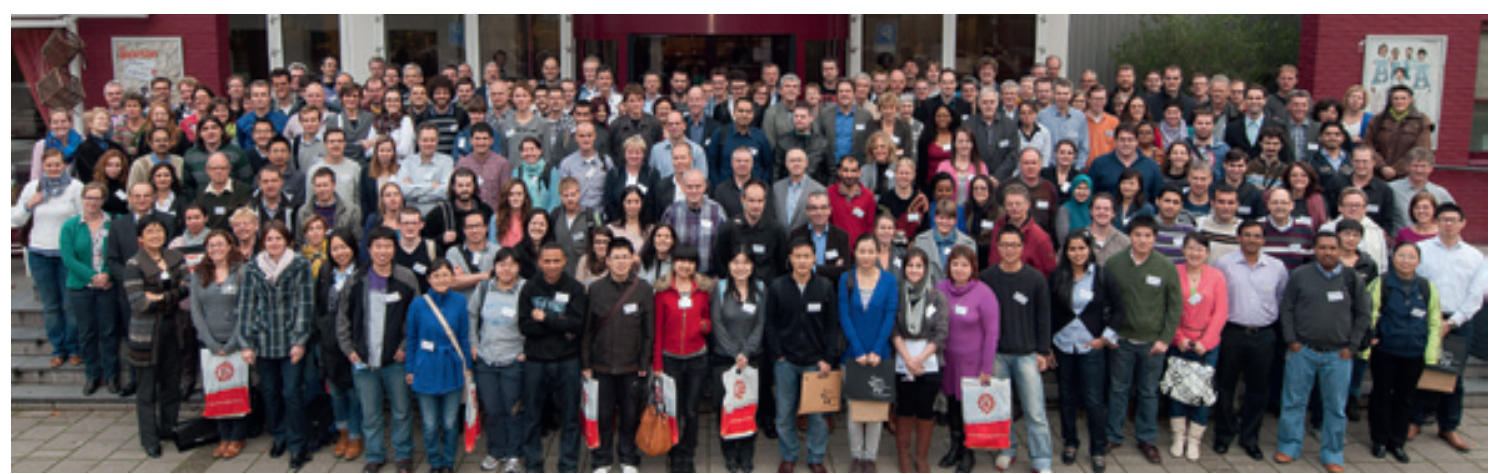

\section{Next generation plant breeding}

De titel van het congres dekte de lading goed: er was veel aandacht voor nieuwe technieken en toekomstige uitdagingen. Hoewel de bijeenkomst werd georganiseerd in het kader van '100 jaar plantenveredeling', naar aanleiding van de oprichting van het Instituut voor Plantenveredeling in 1912, werd er slechts summier teruggeblikt op de klassieke veredeling. Duidelijk werd dat de komst van biochemische en moleculaire technieken een grote verandering heeft gebracht, allereerst in het onderzoek, maar inmiddels ook volop in de praktijk: van isozymen (eiwitvarianten) in de jaren '70, RFLPs (DNA-lengtevarianten op basis van enzymatische knipplaatsen) in de jaren '90 tot SNPs (enkelvoudige basenvariaties in het DNA) in de jaren '00. De selectie vindt daarbij meer en meer plaats op basis van innerlijke kenmerken van de plant en hoe langer hoe minder op basis van uiterlijke.

Vandaag de dag staat ons een groot aantal methoden ter beschikking om de genetische opmaak van organismen te ontrafelen (sequensen). Deze methoden zijn nog volop in ontwikkeling en er bestaan grote machines met enorme capaciteit, maar ook kleine apparaten met lagere (maar toch nog steeds zeer grote) capaciteit. Dit wordt in rap tempo goedkoper: sequentiedata is nu al in veel gevallen veel goedkoper en makkelijker te verkrijgen dan gegevens door waarnemingen aan de plant. Een aparte uitdaging hierbij is hoe we moeten omgaan met de enorme hoeveelheid gegevens die er aan zit te komen. Deze sequencing-methoden veranderen ook de manier van werken in de veredeling: in plaats van met losse allelen wordt er gewerkt met haplotypen: combinaties van allelen die voorkomen op een chromosoom en die gekoppeld kunnen overerven. Wanneer het hele genoom van een aantal planten in kaart is gebracht, kunnen geschikte individuen of kruisingsouders worden geselecteerd.

\section{Wat betekent al die genetische informatie?}

Van lang niet alle stukken DNA in het genoom weet men de functie. De zoektocht naar genen is eigenlijk nog maar net begonnen. Wel vergroot de genetische studie van basenvolgordes ( $g e$ nomics) sterk het inzicht. In de basenvolgorde duiden start- en stopcodons op de aanwezigheid van stukken DNA die kunnen worden afgelezen: dit zijn dan de genen. Op welke eigenschap zo'n gen invloed heeft is dan vaak nog niet duidelijk. In families van genen die in verschillende plantensoorten voorkomen hebben op elkaar lijkende genen vaak ook een soortgelijke functie. Dat is dan een hulpmiddel om de functie van een gen te ontrafelen.

Een andere uitdaging is het ontdekken van genen van kwantitatieve eigenschappen (zogenaamde QTLs - quantitative trait loci). Dit soort eigenschappen is lastig waar te nemen aan planten, zeker als het om kleine aantallen planten gaat. Kwantitatieve eigenschappen worden namelijk 
sterk beïnvloed door de omgeving en het onwikkelingsstadium van de plant.

De studie van de messenger-RNAs biedt inzicht in wanneer en waar bepaalde genen geactiveerd worden en worden afgelezen (transcriptomics). Kennis over de vorming van bepaalde stoffen, compleet met tussenstappen (metabolomics) geven de mogelijkheid om genen te vinden die op bepaalde plaatsen in het metabolisme van de plant tijdelijk actief zijn in bepaalde ontwikkelingsstadia.

\section{Genetische en fenotypische selectie}

Ook wanneer nog lang niet alles bekend is kan de genetische informatie gebruikt worden. Een aanpak daarbij is om planten (kruisingsmateriaal) in twee groepen te verdelen: de onderzoeksgroep en de voorspellingsgroep. De onderzoeksgroep wordt uitgebreid geanalyseerd, zowel genetisch als fenotypisch (uitwendig, gehaltes aan nuttige en schadelijke stoffen, resistenties). De voorspellingsgroep wordt alleen genetisch geanalyseerd. Door statistische samenhang te vinden tussen de genetische en de fenotypische kenmerken kan in de voorspellingsgroep worden geselecteerd op veelbelovende planten. Dit is dus onderzoek en praktijk gecombineerd. Dit levert nu vooral nog winst op bij eigenschappen die moeilijk waar te nemen of te toetsen zijn (bijvoorbeeld bij resistenties tegen lastig te hanteren pathogenen) of waarvan analyses duur zijn (bijvoorbeeld toxines). Aan de andere kant zijn er belangrijke ontwikkelingen gaande in het geautomatiseerd/gerobotiseerd waarnemen van planten met camera's. Uiteraard zitten hier ook de nodige haken en ogen aan, maar het biedt ook mogelijkheden: met bepaalde golflengten licht kan stress in planten al veel eerder worden waargenomen dan bij zichtbaar licht met het blote oog. Potplanten zijn via transportbanden automatisch in grote aantallen te vervoeren naar gestandaardiseerde ruimtes voor gecomputeriseerde waarneming.

\section{Statistiek}

Veel aandacht bij de plantenveredeling in de volgende generatie zal uitgaan naar de statistische pakketten en toetsen die gebruikt gaan worden om de enorme hoeveelheid gegevens te analyseren. Zeer belangrijk daarbij is de kwaliteit van de gegevens: computerprogramma's kunnen beter omgaan met ontbrekende gegevens dan met ruis en foutieve gegevens.

\section{Resistentie}

Naast veredeling op kwaliteitsaspecten, was er tijdens de conferentie veel aandacht voor resistentieveredeling. Er zal in de toekomst vooral vraag

\section{Case: aardappel anders}

Ons denkkader moet soms drastisch veranderen: aardappel is een tetraploïd gewas en groeit daardoor sneller en brengt meer op dan zijn diploïde familieleden. Door zijn tetraploïdie is het gewas lastig te veredelen. Illustratief daarvoor is een ras als Russet Burbank dat al 130 jaar bestaat en nog steeds geteeld wordt. Verder is aardappel niet herhaaldelijk zelf te bevruchten, vanwege de grote inteeltdepressie. Het is niet anders. Of toch wel?

Pim Linthout van Solynta BV liet zien dat ze serieus werken aan diploïde aardappelhybriden. Door op diploïd niveau kruisingsouders te selecteren met de juiste complementaire combinatie van genen kan veel sneller voortgang geboekt worden. Gerichte veredeling is dan mogelijk. De inteeltdepressie kan wel worden uitgeselecteerd. Na veredeling teruggaan naar tetraploïd niveau is mogelijk, maar waarschijnlijk niet nodig: de diploïden geven waarschijnlijk een hogere opbrengst. Linthout trok de vergelijking met maïs, een kruisbevruchter pur sang: de opbrengst die door veredeling en teeltverbetering lange tijd nauwelijks was gestegen ging sterk omhoog na de introductie van hybride rassen.

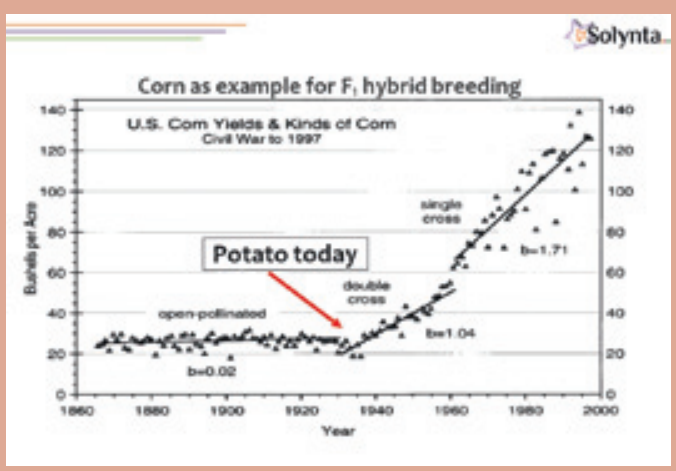

Opbrengst van maïs ter illustratie van de mogelijkheden van hybriden (stijgende lijnen) (bron: website Solynta). 


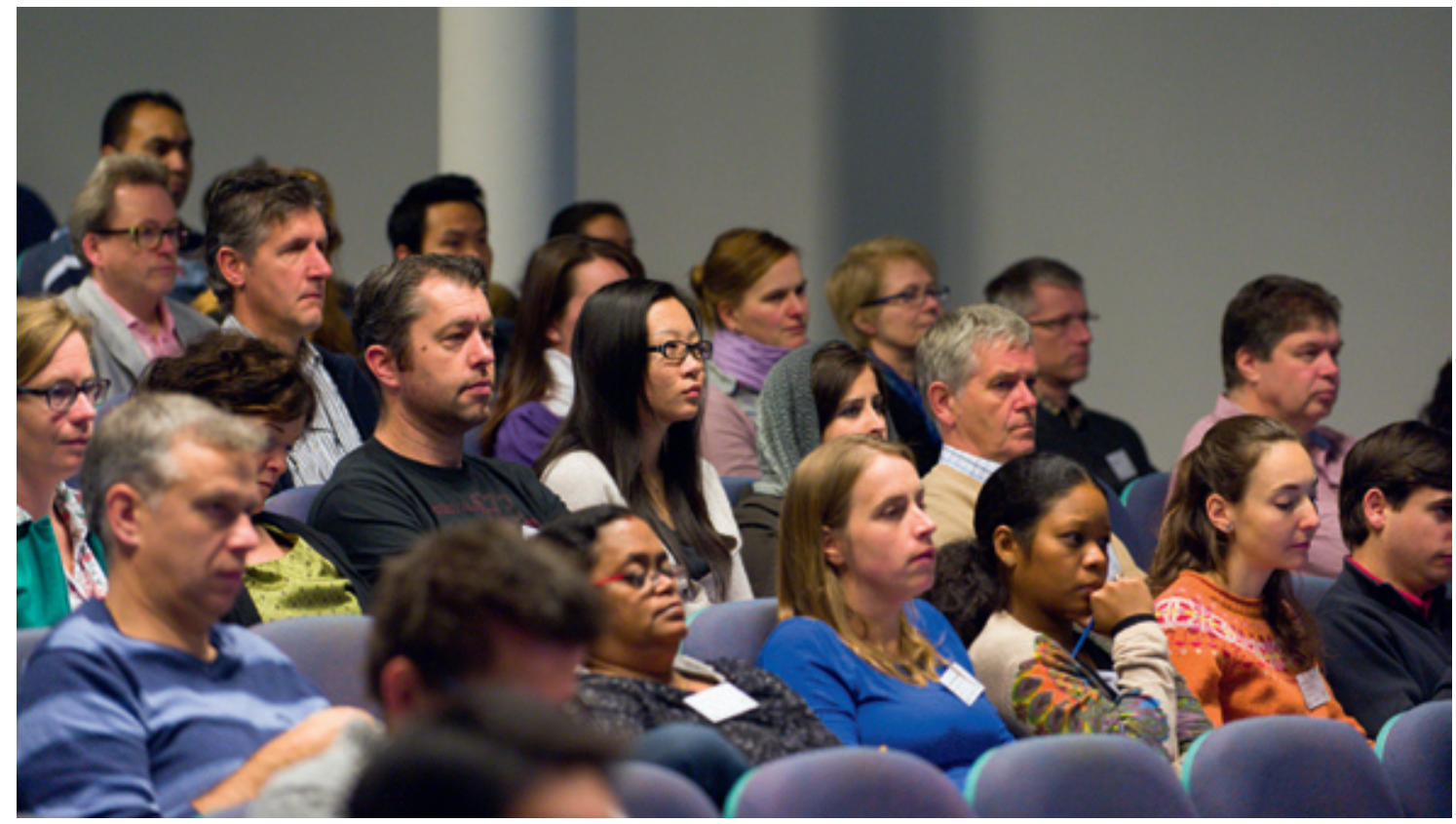

Voor de deelnemers was het een update en een reünie tegelijk (foto's Guy Akkermans).

zijn naar resistenties die niet snel worden doorbroken. De duurzaamheid van resistentie hangt echter af van de variatie in de ziekteverwekkers en van de selectiedruk. Deze bepalen of de populatie aan ziekteverwekkers zich zal kunnen aanpassen. De veredelaar zal zich dus niet alleen in de plant moeten verdiepen.

Vaak ook is er een negatief verband gevonden tussen resistentie tegen abiotische en biotische stress. Het lijkt alsof planten in verwarring zijn wanneer ze te maken hebben met gecombineerde stress.

\section{Geslaagd}

De bezoekers waren zeer positief over de conferentie. Naast een hoog reüniegehalte had de bijeenkomst voor de deelnemers veel informatie te bieden over state of the art onderzoek en praktijk. Daarbij overheerste de focus op de ongekende mogelijkheden voor de (nabije) toekomst. Waar zouden we staan over nog eens honderd jaar?

\section{Nieuw adres of email?}

\section{Pas het zelf aan op de site of geef het door aan ledenadministratie@knpv.org.}

U kunt uw gegevens op www.knpv.org zelf aanpassen door in te loggen met uw inloggegevens. Deze staan op de jaarlijkse factuur en in de elektronische nieuwsbrief en zijn ook op te vragen via de link 'wachtwoord vergeten' of via de ledenadministratie. De inlognaam is doorgaans het emailadres waarmee u uzelf oorspronkelijk bij de KNPV hebt aangemeld en verandert niet automatisch mee met een eventueel nieuw emailadres. De inloggegevens zijn desgewenst te wijzigen door de ledenadministratie.

Door uw gegevens actueel te houden blijft u op de hoogte van de activiteiten van de vereniging. 